\title{
МОНГОЛ УЛС, БНХАУ-ЫН НАЙРСАГ ХАРИЛЦАА, ХАМТЫН АЖИЛЛАГААНЫ ТУХАЙ ГЭРЭЭНИЙ УЛС ТӨР, ЭРХ ЗУЙН АЧ ХОЛБОГДОЛ
}

\author{
Д. ШИрхүY \\ ШУА-ийн Олон улс судлальн хүрээлэн \\ Цахим шуудан: shur121@yahoo.com
}

\section{Монгол-Хятадын харилцааны шинэ үе шатыг баталгаажуулсан түүхт гэрээ}

Эдүгээгээс яг 20 жилийн өмнө Монгол Улсын Ерөнхий сайд П.Жасрайн урилгаар БНХАУ-ын Төрийн Зөвлөлийн Ерөнхий сайд Ли Пэн Монгол Улсад албан ёсоор айлчлал хийх үеэр хоёр орны Ерөнхий сайд нар "Монгол Улс, БНХАУ-ын найрсаг харилцаа, хамтын ажиллагааны тухай гэрээ”-нд гарын үсэг зурсан билээ. Өнөөгийн өндөрлөгөөс эргэн харахад бүх зүйл жам ёсоор болсон мэт санагдаж магадгүй. Гэвч архивын баримт, гэрээ байгуулах бэлтгэл ажлыг гардан хийж байсан ахмад дипломатуудын дурсамжаас үзэхэд нөхцөл байдал амаргүй байжээ. Гэрээний гол “зохиогч”-дын нэг Ц.Гомбосүрэн сайд гэрээ байгуулсан түүхийн тухай тодорхой өгүүллээ. Гэрээний эх бэлтгэх ажилд оролцож байсан хятадын нэртэй дипломат Хуан Зякуй (黄家癸) элчин сайдын дурсамжаас бас иш татмаар байна. Хуан сайдын бичснээр, 1994 оны 4-р сард МАХН-ын Засгийн газрыг огцрохыг шаардан сөрөг хүчин жагсаал цуглаан хийж, Сүхбаатарын талбайд гэр барьж, өлсгөлөн зарлаад байв. Нөхцөл байдал хүндэрч, зарим хэт туйлшрагчид Хятадын Ерөнхий сайд Ли Пэнийг айлчлах үеэр “цус урсгана" гэж хүртэл цуу яриа түгээж байлаа. Иймд төвөөс Монголын нөхцөл байдал ямар байгааг илтгэхийг шаардаж байсан тул ЭСЯ-ны ажилтнууд энэ асуудлыг олон удаа хэлэлцсэн юм.
Нэг хэсэг ажилтнууд Монголын байдал нэлээд ярвигтай, зарим этгээд Хятадыг бай болгож, Монгол-Хятадын харилцааны асуудлыг хөндөж буй тул Ерөнхий сайдын аюулгүй байдлын үүднээс айлчлалыг хойшлуулах санал дэвшүүлж байв. Харин олонх хүн энэ бол түр зуурын, Монголын дотоод зөрчлөөс үүдэлтэй хэрэг. "Цус урсгана" гэдэг бол маш цөөн тооны хэт үндсэрхэх гэмт этгээдүүдийн үг. Монголын улс төрийн намууд, өргөн түмэн Хятадтай харилцаа хөгжүүлэхийг зорьж байгаа нь Монголын гол хандлага. Өлсгөлөн зарласан явдал засгийн газрынхаа эсрэг чиглэсэн цэвэр дотоодын асуудал болохоос Хятадтай холбоогүй тул Ли Пэн ерөнхий сайд ямар ч байсан товлосон хугацаандаа айлчлах нь зүйтэй гэсэн саналыг төвдөө явуулжээ. Ли Пэн даргын айлчлал эхлэхийн өмнөх өдөр Ардчилсан намын Р.Гончигдорж тэргүүтэй нөхдүүд өлсгөлөнгөө зогсоосон тул эсэргүүцлийн ажиллагаа аяндаа тарж, Сүхбаатарын талбай хэвийн байдалд орсоноор Ли ерөнхий сайдын айлчлалын сүүлийн “саад” арилсан ажээ [1]. Үүнийг Элчин сайд асан Д.Цахилгаан гуай мөн нотолдог. Тэрбээр “Хожмоо миний тайлж мэдснээр энэ эгзэгтэй үед Хятадаас 3 шинжээч эрдэмтэн ЭСЯ-ныхаа “зочин”оор ирж байдлыг газар дээр нь судалж үзээд "Монголд болж байгаа явдал суудал дотоодынх нь асуудалтай холбоотой, 
Хятадын эсрэг шинжгүй, найрамдлын гэрээ байгуулахад саадгүй" гэсэн дүгнэлт хийгээд буцсан юм билээ. Ер нь Хятадын төр засаг аливаад эрдэм шинжилгээ, судалгааны байгууллага, олон нийтийн санал бодлыг тунгаан үзэж байж шийдвэр гаргадаг нь сургамжтай” хэмээн бичсэн байдаг [2].

1990-ээд оны эхээр Монгол, Хятад хоёр тал харилцаагаа хэвийн болгох, түүнийгээ эрх зүйн хувьд баталгаажуулахыг машид хүсч, хүч чармайлт тавьж байсныг онцлон тэмдэглүүштэй. Хоёр талын харилцаа хэвийн болгох ажлыг гардан хийж байсан Гадаад явдлын сайд агч Ц.Гомбосүрэн гуай, би 1988 онд ГЯЯ-ны сайдаар томилогдохдоо Монгол-Хятадын харилцааг бүрэн хэвийн болгох зорилтыг цаг үеийн зайлшгүй шаардлага хэмээн ухамсарлаж, аль болох цаг алдахгүйг хичээж байлаа. Харилцааг урагшлуулах талаар хятадын тал илүү

\section{4 оны гэрээнд орсон өөрчлөлтүуд}

1994 оны Гэрээ нь 1960 оны 5-р сарын 31-ны өдөр гарын үсэг зурсан Бүгд Найрамдах Монгол Ард Улс, Бүгд Найрамдах Хятад Ард Улсын хоорондынн Найрамдал, харилцан туслалщах тухай Гэрээ-ний чухал заалтуудыг уламжлан авахын зэрэгцээ шинэ агуулга, заалтуудаар баяжуулан шинэчилсэн юм.

1990 онд Бээжин хотноо, 1991 онд Улаанбаатар хотноо дээд хэмжээний уулзалт, яриа хэлэлцээ хийж, хоёр орны харилцаанд шийдэгдээгүй зарчмын асуудал байхгүй гэсэн нэгдмэл дүгнэлтэд хүрч, харилцаа бүрэн хэвийн болсныг зарласан юм. Үүний дараа хоёр орны дипломатууд хүрсэн энэ түвшинг баталгаажуулах, харилцааны эрх зүйн үндсийг бэхжүүлэх ажилд шамдан орсон билээ.

Юуны өмнө хоёр тал 30 гаруй жил сөхөж хараагүй 1960 оны гэрээгээ шинэ нөхцөл байдалд тохируулан өөрчлөх талаар тохиролцоонд хүрч, түүнд ул суурьтай бэлтгэж эхэлсэн байна. Гэрээний үГ хэллэгийг олон улсын нийтлэг зарчим, хэм идэвхитэй гэхээр байсан хэмээн дурсан бичсэн юм [3]. Ц.Гомбосүрэн, Цянь Цичэнь нарын тулхтай сайд нараар удирдуулсан хоёр орны дипломатуудын ур чадвар, эр зориг, хичээл зүтгэлийн үр дүнд МонголХятадын харилцаа маш богино хугацаанд бүрэн сэргээд зогсохгүй Найрсаг харилцаа, хамтын ажиллагааны гэрээгээр баталгаажсан юм. Хэрэв 1994 онд Ли Пэн ерөнхий сайдын айлчлал хойшлогдсон бол Гэрээг шинэчлэн байгуулах ажил бүр тасардаггүй юм гэхэд нэг хэсэгтээ удаашрах байсан болов уу.

1994 гэрээнд орсон өөрчлөлт, улс төр, эрх зүйн ач холбогдлыг тодотгохын тулд өмнөх 1960 оны гэрээ болон Монгол УлсОХУ-ын хооронд 1993 онд байгуулсан гэрээтэй харьцуулан үзвэл нэлээд сонирхолтой хэмээн бодож байна.

хэмжээнд нийцүүлэн өөрчлөхийн тулд хоёр тал нухацтай хандаж байв. Энэ нь бас хоёр орон үндэсний эрх ашгаа дээдэлсэн, бие даасан, нээлттэй гадаад бодлого явуулж буй бодит байдлаас урган гарч байлаа. Тийм ч учраас "пролетарийн интернационализм", “ах дүүгийн эвдэригүй найрамдал” гэх мэт үг хэллэгийг өөрчлөхийн зэрэгцээ тус тусын эрх ашгийг хөндсөн асуудалд ихээхэн анхаарал болгоомжтой хандаж байв. Гэрээний нэрийг Монгол Улс, Бүгд Найрамдах Хятад Ард Улсын найрсаг харилцаан, хамтын ажиллагааны гэрээ хэмээн өөрчлөв.

Монгол-Хятадын хооронд байгуулсан 1960, 1994 оны гэрээний хамгийн амин чухал заалт бол харилцаа, хамтын ажиллагааны суурь зарчмуудыг тодорхойлсон явдал байлаа. 1960 оны гэрээнд хоёр талын харилцааны үндсэн зарчмуудыг оршил хэсэгт дурдсан бол 1994 оны гэрээнд тусгайлан Нэгдүгээр зүйл болгон “Хэлэлиээн тохирогч талууд бие биеийн тусгаар тогтнол, бүрэн эрхт 
байдал, нутаг дэвсгэрийн бүрэн бүтэн байдльг харилцан хүндэтгэх, харилиан үл довтлох, дотоод хэрэгт үл оролцох, эрх тэгш, харилцан ашигтай байх, энх тайвнаар зэрэгиэн орших зарчмын үндсэн дээр хоёр улсын сайн хөршийн найрсаг харилцаа, хамтын ажиллагааг хөгжүүлнэ" [4] хэмээн оруулжээ. 1960 оны гэрээнд дурдсан тулгуур зарчмууд дээр "Бие биеийн тусгаар тогтнольг харилцан хүндэтгэх", “харилцан үл довтлох”, “энх тайвнаар зэрэгиэн орших” гэсэн 3 заалтыг нэмэн оруулжээ. Үүнээс гадна "НУБ-ылн Дүрмийн зорилго, зарчмыг удирдлага болгох" тухай бас нэг чухал заалтыг оршил хэсэгт шинээр оруулсан байна. Эдгээр шинэ заалт бол хоёр орны харилцаанд 1960-1994 оны хооронд гарсан хувьсал өөрчлөлт, туршлага сургамжаас үүдэн гарсан юм.

1960 оны гэрээний 3-p зүйлд “...энх тайван бүтээн байгуулалтын үйл хэрэгт бие биедээ бүх чадльнхаа хирээр эдийн засаг, техникийн туслалщаа Үзүүлнэ"[5] гэсэн заалт шинэ нөхцөлд таарахгүй болсон тул 1994 оны гэрээнд (2-р зүйл) хоёр талын харилцаа, хамтын ажиллагааг эрх тэгш, харилцан ашигтай байх зарчмын дагуу урт хугацаанд тогтвортой хөгжүүлнэ гэсэн цоо шинэ зарчим, агуулгаар сольсон байна.
Шинэ гэрээнд орсон бас нэг чухал өөрчлөлт бол хоёр тал тив, дэлхийн аюулгүй байдлаас үндэсний аюулгүй байдал, эрх ашгаа чухалчлан үзсэн, прагматик хандлага юм. 1960 оны гэрээний 1-p зүйлд, “...хоёр Тал нь Ази ба даян дэлхийд энх тайван, улс түмний аюулгүй байдлыг сахин хамгаалахын төлөө бүх хүчээр чармайх болно" заасан бол 1994 оны Гэрээнд (3-р зүйл) улс орнуудын харилцаа, хамтын ажиллагааг хөгжүүлэх болон бүс нутаг, дэлхий дахины тулгамдсан асуудлыг шийдвэрлэхэд тус дөхөм үзүүлэх Үүднээс НҮБ болон олон улсын бусад байгууллагын хүрээнд хамтран ажиллана гэсэн даруухан заалт оруулжээ. Харин гэрээний 4-р зүйлд, “Хэлэлцэн тохирогч талууд бие биеийн эсрэг чиглэсэн цэрэг, улс төрийн аливаа эвсэлд оролцохгүй, нөгөө талын төрийн бүрэн эрхт байдал, аюулгүй байдалд хохирол учруулах ямар нэгэн гэрээ, хэлэлцээрийг гуравдагч оронтой байгуулахгүй, аль ч тал нөгөө талын төрийн бүрэн эрхт байдал, аюулгүй байдлыг хохироохоор өөрийн нутаг дэвсгэрийг гуравдагч улсад ашиглуулахгүй” гэсэн цоо шинэ заалтыг оруулж ирсэн нь зүй ёсоор анхаарал татдаг.

\section{Монгол-Орос/1993/, Монгол-Хятадын/1994/ гэрээг жишихүй}

Дэлхий нийт Хятад, Орос хоёр их гүрний дунд орших жижиг Монгол Улс хоёр хөрштэйгээ хэрхэн харилцаж буйг ямагт ажиглан харж байдаг. Монгол Улсын хөгжил цэцэглэл, аюулгүй байдал мөнхийн хоёр хөрштэйгээ тогтоосон харилцаа, хамтын ажиллагаанаас ихээхэн хамаардгийг $\mathrm{XX}$ зууны түүх бэлхэнээ харуулсан билээ. Иймд 1993 оны 1-р сард байгуулсан “Монгол Улс, ОХУ-ын найрсаг харилцаа, хамтын ажиллагааны тухай гэрээ”(6)-г нэг жил гаруйн дараа буюу 1994 оны 4-р сард байгуулсан "Монгол Улс, БНХАУ-ын найрсаг харилцаа, хамтын ажиллагааны тухай гэрээ”-тэй харьцуулан жишихэд нэлээд сонирхолтой зүйлүүд ажиглагдаж байна. Энэ нь дээрх гэрээнүүдийн онцлог, ач холбогдлыг товойлгон гаргахын зэрэгцээ Монгол Улсын зүгээс хоёр хөрштэйгээ тогтоосон харилцаа, хамтын ажиллагаанд гарсан өөрчлөлт, шинэчлэлт, хөгжлийн цаашдын төлөв хандлагыг ойлгоход ихээхэн тус дөхөмтэй хэмээн үзэж байна.

Энэхүү хоёр гэрээ нь байгуулсан цаг хугацааны хувьд ойролцоо, нэрийн хувьд ижилхэн байна. Харин Монгол-Оросын гэрээг Москвахотноо төрийнтэргүүнүүдийн хэмжээнд байгуулсан бол Монгол-Хятадын гэрээнд Улаанбаатар хотноо Ерөнхий 
сайд нар гарын үсэг зуржээ. Дашрамд дурдахад Монгол-Хятадын хооронд 1960, 1994 онд байгуулсан гэрээнүүдийг бүгдийг Улаанбаатар хотноо, Засгийн газрын тэргүүнүүд гарын үсэг зурсан байна.

Монгол-Хятадын гэрээ ердөө 6 зүйлтэй нэлээд товчхон байхад Монгол-Оросын гэрээ нь харьцангуй олон салбарыг хамарсан 20 зүйл бүхий нэлээд дэлгэрэнгүй шинжтэй байна. Гэрээний үйлчлэх хугацааг ч өөр байдлаар тогтоожээ. Монгол-Оросын гэрээг 20 жилийн хугацаатай байгуулж, хэрэв гэрээний хүчин төгөлдөр байх хугацаа дуусахаас 12 сарын өмнө аль нэг тал нь түүнийг цуцлах тухайгаа бичгээр нөгөө талдаа мэдэгдээгүй бол тав таван жилээр аяндаа сунгагдах байдлаар талууд тохирсон байна. Монгол Хятадын гэрээг хугацаагүй буюу урт удаан хугацаанд хүчин төгөлдөр байхаар талууд тохирсон бөгөөд хэрэв аль нэг тал нь энэхүү гэрээг хүчингүй болгохыг хүсвэл энэ тухайгаа хэлэлцэн тохирогч нөгөө талдаа нэг жилийн өмнө бичгээр мэдэгдэж болно хэмээн дурджээ.

Монгол Улс хоёр хөрштэйгээ байгуулсан Найрсаг харилцаа, хамтын ажиллагааны тухай гэрээнүүдэд нэлээд нийтлэг зарчим, хандлага ажиглагдаж байна. Тухайлбал, өөр хоорондын харилцаандаа тусгаар тогтнол, бүрэн эрхт байдал, нутаг дэвсгэрийн бүрэн бүтэн байдлыг хүндэтгэх, дотоод хэрэгт үл оролцох, хүч үл хэрэглэх, харилцан ашигтай, эрх тэгш харилцах, НҮБ-ын зорилго, зарчмыг удирдлага болгох гэсэн зарчмуудыг баримтлахаар тохирсон байна. Мөн түүнчлэн гадаад бодлого, аюулгүй байдал, гуравдахь этгээдтэй харилцах талаар хоёр гэрээнд ижил буюу төстэй заалтууд нэлээд тусгагдсан нь Монгол Улсын хоёр хөрштэйгээ тэнцвэртэй харилцах зарчмын байр суурьтай ихээхэн холбоотой юм.

ОХУ, БНХАУ-ын хөгжлийн зам, гадаад бодлогын уламжлалтай холбоо зарим нэг онцлог үг, хэллэгээр гэрээнүүд бас ялгарч байлаа. Жишээ нь, Монгол-Хятадын гэрээнд орсон энх тайвнаар зэрэгцэн орших зарчим Монгол-Оросын гэрээнд байхгүй боловч хүний эрх ба үндсэн эрх чөлөө, улс түмний тэгш эрх, хувь заяагаа өөрсдөө шийдвэрлэх эрхийг хүндэтгэх гэсэн Монгол-Хятадын гэрээнд дурдагдаагүй зарчмуудыг оруулсан байна.

Түүнээс гадна Монгол-Оросын гэрээ нь хөтөлбөрийн шинж давамгайлсан дэлгэрэнгүй, Монгол-Хятадын гэрээ нь суурь зарчим, ерөнхий чиг хандлагыг тодорхойлсон тунхагийн шинж давамгайлсан онцлог ажиглагдаж байна. Иймд бүтэц, зохиомжийн хувьд харилцан адилгүй хоёр гэрээг зүйл, салбар, чиглэл бүрээр жишин үзэхэд тохиромжгүй болох нь тодорхой юм.

Эцэст нь 1994 оны Монгол-Хятадын гэрээний улс төр, эрх зүйн ач холбогдлыг дараахь 3 чиглэлээр тодорхойлж болмоор санагдаж байна. Үүнд:

1-рт, Монгол Улс, БНХАУ-ын найрсаг харилцаа, хамтын ажиллагааны тухай Гэрээний түүхэн ач холбогдол хоёр улсын харилцаа, хамтын ажиллагааны ирээдүйн хөгжлийн эрх зүйн шинэ баталгаа болж, хоёр улсын харилцааны үндсэн зарчим, хэм хэмжээг тодорхойлсонд оршино.

2-рт, Энэхүу гэрээ нь бүс нутагтаа үр нөлөө бүхий Монгол-Хятадын стратегийн түншлэлийн харилцааг бий болгох, хөрш орнуудын үлгэр жишээ харилцааг цогцлооход чухал суурь дэвсгэр болно. Дашрамд дурдахад 2013 оны 10-р сард хоёр орны Ерөнхий сайд нар гарын үсэг зурсан “Стратегийн түншлэлийн харилцааг хөгжүүлэх дунд, урт хугацааны хөтөлбөр"-т Монгол, Хятадын стратегийн түншлэлийн харилцааг улс хоорондын харилцааны үлгэр дууриал болгоно хэмээн заасан билээ.

3-рт, Хоёр орны найрсаг харилцаа, хамтын ажиллагааны хэтийн төлвийн талаар эргэлзсэн, найрсаг бус, гутранги үзэл бодолтой цөөн тооны дотоод, гадаадын хүмүүст 1994 оны МонголХятадын гэрээ дорвитой няцаалт, бодитой хариулт болж чадна. Эдүгээ Монгол, 
Хятад хоёр орон эрчимтэй хөгжил, эрс шинэчлэлийн эгзэгтэй, хариуцлагатай үе шатандаа байна. Хоёр талын харилцаанд урьд өмнө нь байгаагүй цоо шинэ нөхцөл байдал, асуудал бэрхшээл, өрсөлдөөн сорилт тулгарч байна. Ийм нөхцөлд 1994 онд байгуулсан "Монгол Улс, БНХАУ-ын найрсаг харилцаа, хамтын ажиллагааны тухай Гэрээ"-нд заасан тулгуур зарчмууд бол дотоод, гадаадын элдэв хардлагад няцаалт болохын зэрэгцээ хоёр ард түмний найрсаг харилцаа, итгэлцлийг бэхжүүлэх чухал үндэс суурь болж байна.

\section{Ашигласан бүтээлийн жсагсаалт}

1. Хуан Зякуй. Монголд тавантаа томилогдсон минь /黄家骙, 五进蒙古/, Өвөр Монголын Их сургууль, 2008, 65-р тал

2. Д.Цахилгаан. Мөнхийн хөршийнд мөн ч удсан даа. // "Найрамдал, хамтын ажиллагааны нэгэн жаран”, Бээжин 2009, 321-р тал

3. Ц.Гомбосүрэн. Харилцаа бүрэн хэвийн болохыг үзсэн шүү. // “Найрамдал, хамтын ажиллагааны нэгэн жаран”, Бээжин 2009, 198-р тал

4. МОНГОЛ УЛС, БҮГД НАЙРАМДАХ ХЯТАД АРД УЛСЫН НАЙРСАГ ХАРИЛЦАА, ХАМТЫН АЖИЛЛАГААНЫ ГЭРЭЭ // "Найрамдал, хамтын ажиллагааны нэгэн жаран”, Бээжин 2009, -р тал

5. БҮГД НАЙРАМДАХ МОНГОЛ АРД УЛС, БҮГД НАЙРАМДАХ ХЯТАД АРД УЛСЫН ХООРОНДЫН НАЙРАМДАЛ, ХАРИЛЦАН ТУСЛАЛЦАХ ТУХАЙ ГЭРЭЭ// “Найрамдал, хамтын ажиллагааны нэгэн жаран”, Бээжин 2009, -р тал

6. Монгол-Оросын харилцаа. Баримт бичгүүд. 1991-2004 он, ШУА-ийн Олон улс судлалын хүрээлэн, Улаанбаатар хот, 2006 он, 24-28-р тал 